\title{
IMPACT OF HUMANITIES ON THE FORMATION OF A MEDICAL STUDENT AS PERSONALITY
}

\section{Isayeva $\mathbf{O} . \mathrm{S}$.}

\section{INTRODUCTION}

The National Strategy for the Development of Education in Ukraine has been adopted defining a set of measures for 2012 to 2021 to ensure the priority development of education, the core of which is developmental, cultural-forming dominant, and to nurture a spiritually and morallydeveloped personality, who is capable of mobile adaptation in a fast-paced world, self-realization in society, using obtained information to creatively solve professional concerns and issues.

The main danger of the $21^{\text {st }}$ century civilization is dehumanization of the human being, students' transformation to hi-tech machines of wishes and mass consumption without humane, cultural and personal characters. Present generation is totally aware of personal, social and moral responsibilities towards future. Nevertheless, there is a moral obligation to formulate behavioral guidelines for medical students within a broad and futureoriented perspective related to professional duties.

Consequently, nowadays the most urgent question is the use of technology in training an innovative personality using key competencies. The researcher ${ }^{1}$ notes that modernization and implementation of inventive teaching methods of humanities at Ukrainian higher medical institutions is currently more significant than ever before. Thus, search for new approaches is being activated to teach and to learn humanities at medical universities; pedagogical technologies are being developed aimed at the implementation of the principles in the teaching process. Humanitarian disciplines substantially stimulate the development of moral and ethical students' ideal at medical universities as the contextual element of humanities has a significant potential. Such qualities as compassion, tolerance, decency and understanding should be formed in students of medical specialties while studying social and humanitarian disciplines that will provide parity relations and special emotional interconnection between a doctor, staff and a patient.

${ }^{1}$ Isayeva O.S., Isayeva O. Modeling Cultural Competence in Teaching Humanities to Medical Students. American Journal of Educational Research (Education). 2014. Vol. 2 (12B). P. 51-55. 
In Ukraine social significance and complexity of medical professional duties require high level of training, fundamental knowledge of the theory and practice of medicine, mastering skills, tactics, techniques, and appropriate methods of medical practice. Doctor's activities aimed at protecting the interests of patients and society in preserving human life and health.

However, at higher medical educational institutions, the study process of humanities is sometimes limited to simple text retelling from the textbook: mastering of knowledge occurs through the sample and demonstration, culminating in a more or less conscious understanding and memorizing of the considered material. The scarcity of resources and knowledge, the lack of policies and curricula for skills development, domination of traditional teaching methods, the insufficiency of creative tools, and narrow test-based assessment ${ }^{2}$, are the main reasons to reform Ukrainian higher medical educational system fundamentally.

Therefore, absolute priority of developing a culturally inspired and free personality of a future medical specialist, capable of self-realization, selfexpression and self-development is observed in the context of teaching humanitarian subjects. The purpose of humanities should be goals to teach a person to think, to analyze, to solve, and to assess various and controversial facts of professional activities or events in the community and as a result they should be able to create new methods of treatment, diagnosis and innovative options in research.

Humanitarian education should enhance a medical student's ability of self-analysis, self-awareness, self-reflection as well as surrounding events. Moreover, it should make students think productively and innovatively, that means to create new and worthwhile ideas (both incremental and radical concepts), elaborate, upgrade, analyze, assess and find original solutions to improve and maximize creative efforts. Block of humanitarian sciences should provide necessary skills and competencies for future health professionals, which will gradually be implemented into practical activity.

We should remember that a crucial element in the system of higher education is social and humanitarian training of future medical specialists. An important task of humanitarian education is to form a physician of international level, intellectual personality, the core of which being

2 Banaji S., Cranmer S. \& Perrotta C. Expert Perspectives on Creativity and Innovation in European Schools and Teacher Training. Luxembourg : European Commission Joint Research Centre Institute for Prospective Technological Studies. 2010.

${ }^{3}$ Brady R., \& Edelman L.A. State of Create Global Benchmark Study: Global Benchmark Study on Attitudes and Beliefs about Creativity at Work, School and Home. 2012. 
Ukrainian national idea, i.e. the formation of national consciousness, the development of national dignity and self-respect.

However, professional education is considered as the fact of culture and ethics in professional culture or as an event in personal culture and bioethics. As Daniel Pink remarked, "The future belongs to a very different kind of person with a very different kind of mind - creators and empathizers, pattern recognizers and meaning makers. These people... will now reap society's richest rewards and share its greatest joys" ${ }^{4}$. If students leave any educational establishment without knowing how to continuously create and innovate, they will be underprepared for the challenges of society and the workforce.

The aim of the research is to analyze pedagogical approaches to the formation of students' skills and traits of character at higher medical educational institutions; to support innovations of educational training system focusing on the development of a free personality, improving the quality of education and promoting competences being significant for medical students.

Methods used include analysis, synthesis and modeling; exploring different conceptualizations of pedagogy and their implications into teaching process; demonstration of the relationships between theoretical directions, pedagogical context and research approach.

\section{Cultural competence as key component in medical education}

The content of contemporary medical training as the foremost level of the educational system in Ukraine is reoriented intensively into the idea of humanitarian culture, which is based on the improvement of humanitarization, consciousness, morality and spirituality. Even pragmatic American scientists of higher education obviously ponder over whole alternative versions and conclude to implement the courses providing general cultural development and training of emotional and imaginative thinking in future medical specialists. Thus, the main goal of a systematic study at medical universities is primarily to help prepare higher class professional, a creative and skilled specialist, who actively uses in own career creativity, deep thinking, all-round knowledge and experience in various areas of human activity.

It is well-known that the Ministry of Education recommends forming cultural competence in the process of teaching humanities at Ukrainian

\footnotetext{
${ }^{4}$ Bittersweet $K$. Preparing 21st Century Students for a Global Society An Educator's Guide to the "Four Cs" Great Public Schools for Every Student. 38 p. 
medical universities. The scientist Yu. Fokin ${ }^{5}$ marks "Humanity formation of higher education is one of the ways in the development of spirituality, intelligence formation in graduates, overcoming narrow professional technicism thinking of specialists who in addition to solving their specific professional tasks have to perform a highly important mission as preservation and development of people's culture and their civilization". Therefore, cultural competence for medical caregivers is frequently interpreted as a significant constituent and a set of coherent skills, knowledge and attitudes related to: a) knowledge of epidemiology and differential effects of treatment in various ethnic groups; b) skills for dealing with cultural diversity, hereunder communication; c) attitudes such as humility, empathy, curiosity, respect, sensitivity and awareness ${ }^{6,7}$.

Correspondingly, cultural competence is a key constituent to better understanding of diverse students, their families, friends and societies and to increase results and to decrease disparities providing medical service. Cultural competence is considered to be as the ability to successfully teach students with different cultures. It leads to develop certain traits and characters of personal and interpersonal awareness and sensitivity, to appreciate unfamiliar culture and to gain a set of skills, which together entail effective cross-cultural and responsive teaching ${ }^{8}$. Consequently, cultural competence should be interpreted as clusters of: (1) patient's cultural background (e.g., customs, traditions, culture, habits, sexual orientation, race, religion, gender identity, values); (2) health provider and health care (e.g., clinical skills and professional abilities, ethics, bioethics and deontology, awareness, patient-centeredness, and professionalism); (3) appropriate communication skills (e.g., responding to patients' unique requirements, stereotype avoidance and health disparities, case history); (4) cross-culture (e.g., idiomatic expressions, examples of effective communication, media reports); resources for management of cultural competence diversity (e.g., translator guides, instructions and community resources).

In Ukraine, the motives of humanity, arising mainly in the political sphere, are reflected in the philosophical, educational and religious concepts.

${ }^{5}$ Фокин Ю.Г. Преподавание и воспитание в высшей школе: Методология, цели и содержание, творчество : учебное пособие для студ. высш. учеб. заведений. Москва, 2002. 224 с.

${ }^{6}$ Seeleman C., Suurmond J., Stronks KCC. A conceptual framework for teaching and learning. Med Educ. 2009. URL: https://doi.org/10.1111/j.1365-2923.2008.03269.x.

7 Betancourt J.R. Cross-cultural medical education: conceptual approaches and frameworks for evaluation. Acad Med. 2003. № 78 (6). P. 560-569.

${ }^{8}$ Moule J. Cultural Competence: A primer for educators. Belmont, CA : Wadsworth, 2011. 384 p. 
One should remember that the problem of harmonious development of an individual as a fundamental goal of education and training is constantly changing according to historically and socially evolving system of beliefs. Therefore, humanitarization of modern medical education implies that human life should be governed by new values and ideals, a new civilization must respond to the ideas of humanism, morality, and culture. Nevertheless, modern education at higher medical universities is the most technological area of activity directly related to the formation of well-educated future physician and the development of spiritual and moral values of society. Cultural competency is an integral skill set vital to a fruitful physicianpatient relationship. However, we lack tools necessary to assess and teach such skills, especially at the fellowship level". It means that "cultural humility incorporates a lifelong commitment to self-evaluation and selfcritique, to redressing the power imbalances in the patient-physician dynamic, and to developing mutually beneficial and nonpaternalistic clinical and advocacy partnerships with communities on behalf of individuals and defined populations" ${ }^{\prime 10}$. The use of broader range of knowledge and skills will be mediated by attitudes and values (e.g. motivation, trust, respect for diversity and virtue). The attitudes and values can be observed at personal, local, societal and global levels ${ }^{11}$.

There are also basic skills of cultural competence which should be formed in the process of teaching humanities to future medical physicians:

1) valuing diversity: accepting and respecting different cultural backgrounds or customs, dissimilar ways of communication, and disparate traditions and values;

2) being culturally self-aware: understanding educators' own culture (all their experience, background, knowledge, skills, beliefs, values, and interests) which they should apply in the interaction with students;

3) understanding the dynamics of cultural interactions: accepting factors as historical or cultural experience and relationships between cultures in a local community;

${ }^{9}$ Balzora S., Abiri B., Wang X.J., McKeever J., Poles M., Zabar S., ... Weinshel E. Assessing cultural competency skills in gastroenterology fellowship training. World Journal of Gastroenterology. 2015. № 21 (6). P. 1887-1892.

${ }^{10}$ Tervalon M., Murray-Garcia J. Cultural humility versus cultural competence: a critical distinction in defining physician training outcomes in multicultural education. J Health Care Poor Underserved. 1998. № 9. P. 117-25.

${ }^{11}$ URL: https://www.oecd.org/education/.../E2030\% Correlation between creativity and independence20Position $\% 2$. 
4) institutionalizing cultural knowledge and adapting to diversity: forming educational environment based on the understanding of students' culture and learning environment ${ }^{12}$.

In 2014 a Dutch study, C. Seeleman ${ }^{13}$ demonstrated that medical doctors and students lack knowledge of cultural competence and culturally competent behaviour, including experience using interpretation services. However, significant steps toward cultural self-understanding for medical students are to become fully engaged with personal perceptions, behaviors and communication patterns in order to provide culturally competent service. Cultural competence focuses on the capacity of the health workers to improve health status by integrating culture into the clinical context. It is recommended to distinguish the following concepts of cultural competence in teaching humanities at higher medical educational establishments:

1) to understand the meaning of culture competence for health care providers;

2) to achieve cultural competence as future doctors;

3) to apply cultural competence to studying process and future doctor's career;

4) to increase students' organizational cultural competence;

5) to create cultural environment;

6) to differentiate doctor's cultural behavior;

7) to form cross-cultural communication skills.

It is assumed that cultural competence defines a leadership style at the educational institution and even in the group, makes key supervision of personnel actions and has a direct impact on the educational, humanitarian and learning process of medical students. According to conducted survey of students studying General medicine at Danylo Halytsky Lviv national medical university (232 second-year students, 2018-2019 academic year), the content of traits of a doctor as "a person of culture" includes:

1. spirituality: conscientiousness, self-awareness, assertiveness, striving for self-perfection, serving people, humaneness;

2. communication: tolerance, sociability, listening skills, veracity, modesty, empathy, thoughtfulness;

3. morality: good manners, bioethics and deontology, patriotism, honesty, sense of duty, justice;

12 King M.A., Sims A. \& Osher D. How is cultural competence integrated into education? Washington. D.C. : Center or Effective Collaboration and Practice. American Institutes for Research. 2007.

13 Seeleman C., Hermans J., Lamkaddem M., Suurmond J., Stronks K., Essink-Bot M.L. A students' survey of cultural competence as a basis for identifying gaps in the medical curriculum. BMC Med Educ. 2014. 
4. creativity: striving for novelty, curiosity, ability to fantasize, avoiding clichés and patterns;

5. independence: ability to make responsible decisions, self-discipline, life-long learning.

The students also detected the significance of traits of a doctor for their future career as shown on the pie chart:
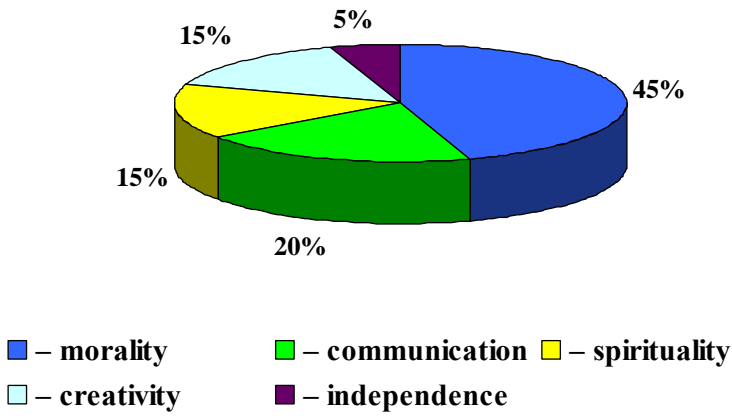

Thus, the background of cultural competence at higher medical universities may be regarded as those acquired skills which help medical students understand cultural dissimilarities and assist communication between patients, their relatives and co-workers who have different views of understanding health, sickness and body functioning. The elements of effective patient-provider communication ${ }^{14}$ comprise:

- to build relationships,

- to open the discussion,

- to gather information,

- to understand the patient's perspective,

- to share information,

- to achieve agreement on problems and plan management,

- to provide confidence.

The development of cultural competence is based on proficiency, competency, personal preferences, cultural background and environment. Investigating education concept, the author further confirms that "the model of the future specialist is reflected, including self-esteem, tolerance, orientation to social and professional self-determination and self-realization,

${ }^{14}$ Makoul G. Essential elements of communication in medical encounters: The Kalamazoo Consensus Statement. Acad. Med. 2001. № 76 (4). P. 390-393. 
ability for making decisions and taking responsibility for them" ${ }^{\prime 1}$. As we know, the practitioners have a wide range of symptoms and signs at their disposal that provide a multi-faceted and deep analysis of clinical manifestations of a patient's disease, its symptoms and arguments to identify specific postulates for the construction of diagnostic hypotheses and enhanced clinical diagnosis for the patient.

A lot of studies have demonstrated that learning process in a multicultural background helps medical students "to deepen knowledge, improve skills and competencies, form values and attitudes" 16 , improve cultural competence at higher medical establishments and contribute its enhancement in future medical activity and public engagement. Accordingly, methods for enhancing cultural competence in a multicultural Ukrainian society should be regarded as policies presented to address the challenges of assessing teachers, parents and families of diverse culture, their beliefs, customs, traditions, and special requirements. Cultural competence among health professionals is viewed as one strategy to confirm equal access to healthcare across diverse groups and to ensure that patients receive care by their needs ${ }^{17}$.

However, it has been previously mentioned, that medical students should demonstrate their gaining of knowledge, ethics, behavior, attitudes, abilities and skills through reflections in seminars, projects or presentations, and even small investigations. As medical students participate in various settings, they develop an appreciation and empathy for the predispositions, stressors, and patients' problems encountered on doctors' daily routines. Students as future caregivers of higher medical universities should provide a service to another person or group while developing knowledge, skills, abilities and attitudes consistent with the overall goals of the curriculum.

As it is confirmed formerly, teachers must provide medical students the chance to check personal role in the process of training and formation of cultural competence. Teachers of humanitarian subjects should elaborate and implement proven and adopted methods and schemes into educational process allowing students to become active, responsible life-long learners

15 Бордовская Н.В., Титова Е.В. Качество деятельности преподавателя вуза (подходы к пониманию и оценке). Вестник СЗО РАО «Образование и культура Северо-Запада России». Санкт Петербург, 2002. Вып. 7. С. 192-206.

${ }^{16}$ Mukan N., Yaremko H., Kozlovskiy Yu., Ortynskiy V., Isayeva O. Teachers' continuous professional development: Australian experience. Advanced Education. 2019. № 12. P. 105-113.

${ }^{17}$ Beach M.C., Price E.G., Gary T.L., Robinson K., Gozu A., Palacio A., Smarth C., Jenckes M., Feuerstein C., Bass E.B., Powe N.R. \& Cooper L.A. Cultural competence: A systematic review of health care provider educational interventions. Medical Care. 2005. № 43. P. 356-373. 
and self-motivated, independent, self-aware, self-managing, self-confident, emotionally stable and intelligent, culturally competent professionals in the field of medicine.

The concept of "pedagogy of cooperation", "pedagogy of co-creation", suggested by Ukrainian scientists Ye. Illyin, V. Karakovskyi, V. Shatalov, M. Shchetinin, has a real embodiment in work conditions of higher medical educational institutions. This concept implies mutual need and interest in coactivity, information enrichment, increased personal influence and attractiveness of the teacher, etc. A good teacher becomes an idol for a medical student, an ideal in future career. Such a teacher can transfer the style of her/his critical thinking, manners and techniques of practical actions, realization methods of cultural, ethical and deontological principles.

\section{Assertiveness as an important skill for future physicians}

Moral education at the medical university is a rather complex process due to the fact that the moral character of most students is predetermined by family traditions which are considered to be a crucial factor in formation of young medical personality. As a trait of character, assertiveness can give the means of adapting students' behavior in precise situations in order to better express own personality and to obtain more satisfaction of personal and professional environment. According to S. Stein and H. Book ${ }^{18}$ "Assertiveness consists of three main components: (1) the ability to express feelings, (2) the ability to openly express beliefs and thoughts (to be able to express own opinion, not to succumb to pressure and to maintain a certain position, even if it is emotionally difficult, and even if you lose while doing something) and (3) the ability to protect their individual rights (not to pester or authorize others to use any person). Confident people are not constrained and timid - they are able to express their feelings (often straight) without aggression and offensive superiority". Well-experienced doctor should know what is actually happening and to feel assertiveness in situations as it is helpful to be knowledgeable about persons involved.

It is necessary to note that an assertive person adopts a fixed or predetermined style of communication which is not responsive to the peculiarities of the situation or to the demands of the relationship. In fact, a future doctor is alert to the realities of the moment and can monitor himself as well as read other people's non-verbal hints or demands. Therefore, medical students should study to be particularly careful with their tone and body language; keeping the objectives of the interaction in mind. In other words, an assertive person communicates to achieve the situational

${ }^{18}$ Stein S.J., Book H.E. The EQ Edge: Emotional Intelligence and Your Success Jossey-Bass; 3 edition. 2011. 368 p. 
objectives, keeping the relational objectives in mind and staying calm in stressed or urgent situations. Besides, it gives students the ability to have a critical analysis of existing circumstances and cases as well as to supplement and create their own ones.

Consequently, formation of assertiveness as a personal trait primarily implies that a person is aware of how behavior is determined by his own inclinations and motivations, and how someone imposes settings. As the researcher ${ }^{19}$ declares that "self-confidence is an acceptance of their actions, decisions, skills as correct and relevant (i.e. acceptance of oneself)" which is significant for future medical caregivers. Thus, assertive behavior of future doctors does not always lead to goals, but the aim emphasizes positive assessment of personality's traits. Personal achievement reinforces the desire to reach other goals, the result as the sense of movement and self-esteem. In this context, N. Telychko ${ }^{20}$ defines two factors which perform a decisive influence on ensuring talent development, personal abilities, achievement of students' life success: genetic (inherited inclinations) and social (education, upbringing and environment). However, the researcher notes that genetic factor is necessary, but social one is sufficient to ensure effective development of personal predispositions of each student. Optimal realization of students' own potential in various activities contributes to adequately diagnose, appropriately design and further develop their personal qualities and parameters.

We consider that humaneness as a part of assertiveness is a moral quality that characterizes the relationship between doctors and patients which is derived from the essence of social work that is one of its characteristics appearing in different forms, the most common of which being altruism as manifestation of unselfish care for others' benefit and willingness to sacrifice for their personal benefits. At the level of moral consciousness altruism is formed in a consistent principle of strengthening humanistic relationships through active and purposeful elimination of the sources of human suffering. Expressions of humaneness in the relationships between a doctor and a patient foster bonds of trust, enabling doctors and patients to enhance diagnostics, compliance and treatment. Thus, patients' belief means doctors' assertiveness:

Beliefs about health: (What caused your illness/problem?)

Explanation: (Why did it happen at this time?)

Learn: (Help me to understand your belief/opinion.)

${ }^{19}$ Скотникова И.Г. Проблема уверенности: история и современное состояние. Психологический журнал. Москва, 2002. Т. 23. № 1. С. 52-60.

${ }^{20}$ Теличко Н.В. Організація навчання обдарованих молодших школярів у США : автореф. дис. ... канд. пед. наук. Івано-Франківськ, 2005. 21 с. 
Impact: (How is this illness/problem impacting your life?)

Empathy: (This must be very difficult for you)

Feelings: (How are you feeling about it?) ${ }^{21}$

Equally, assertiveness may be formed by means of real understanding of responsibility for own emotions, opinions, and actions by future medical professionals. From the first year of study each medical student should realize the nobility of treating patients to achieve the results of well-known doctors and scientists. Thus, a teacher should know how to interact with students for gathering useful information in teaching skilled assertiveness and allowing assertiveness to happen (listen to what the other person is going to say; explain the situation with arguments and slowly using communication strategies). Asertiveness as a key skill for doctors may be acquired due to personal relationships and professional situations.

As all ideas concerning the optimization and restructuring of medical services in Ukraine take place, however, there is still the premise that medicine must start with the patient and communication places an important role in this process. Thus, the absence of communication and counseling skills training in students' curriculum makes it difficult for doctors to convey bad news about diagnosis or patients' general condition. The lack of training in negotiation skills for discussing treatment plans often results in poor compliance and medical legal problems due to divergences between patients' and doctors' views on clinical reality. The process of teaching cross-cultural communication includes linguistic, historical, aesthetic, humanistic and ethical components. A set of interactive methods is used as contemporary teaching approaches, the main point of which is that the teacher and the student are involved in search for information with a variety of communication techniques.

The researcher E. Hall ${ }^{22}$ postulated that the style of communication can vary from a high context culture, where background information is implicit to a low context culture and much of the background information must be made explicit in the interaction. People from high context cultures often send more information implicitly, which means that openness is perhaps not the norm. Thus, in such settings an open style of communication may not be appreciated, especially when conformity is expected. During the process of learning, a teacher can communicate important information to students about their ability to learn and the way they learn. Therefore, it is important to

${ }^{21}$ Dobbie A.E., Medrano M., Tysinger J., Olney C. The BELIEF instrument: a preclinical teaching tool to elicit patients' health beliefs. Family Medicine. 2003. 35. P. 316-319.

${ }^{22}$ Hall E.T., Hall M.R. Hidden Differences: Doing Business with the Japanese. Anchor Press. Doubleday. Garden City : NY, 1987. P. 16-18. 
share assertiveness during the training years of medical students. Such training should, in fact, be imparted in some form to students of every age group. The researchers suggest a model of interpersonal communication that mutual understanding improves perceptual accuracy and communication ${ }^{23}$. It should be noted that assertive doctors are very receptive; therefore, it is easier to communicate with them, they are good listeners and ready to rationally evaluate what is presented and look for agreement.

According to own experience, teaching skilled assertiveness successfully may be hampered without gathering practical information: give students examples of assertive communication techniques, listening techniques, give examples of scenarios and ask to compose own story. Following the principles of self-organization and self-education in pedagogical activity is aimed at creating the educational system to study self-regulation processes at the educational institutions, identifying tendencies, internal mechanisms and reserves of created system without copying already existing samples in pedagogical activity. ${ }^{24}$

Assertive doctors are characterized by independence and self-sufficiency, which is manifested in various spheres of life and career, but the most obvious - in the sphere of interpersonal relationships with doctors and patients. External signs of confident behavior also become most clearly visible in everyday doctors' circumstances. Confident behavior means assertiveness as an integral part of future doctors' activity characterized by such features as: tolerance, purposefulness, creation, patience, reflection etc. In addition to the above-mentioned behavioral aspects that can be ascribed to assertive doctors, it is significant to see how they differ in the perceptual and cognitive processes that govern behavior. A student may be able to display "assertive" behavior at all times because a person's assertiveness is dependent on his/her attitude to "himself/herself", "the other" and perception of the situation. In addition, emotional condition is most likely to influence perception and understanding of interpersonal communications in future medical career. Accordingly, future medical caregivers should achieve practical experience of ethical communicative competence even in critical situations despite of their personal or emotional condition:

- flexibility, ability to formulate problems, adequate reaction to the rapidly changing urgent situations;

- social orientation, focus on constructive relationships with partners, patients

23 Robbins S.P. Understanding cultural differences. Organizational Behavior. Yarmouth. ME : Intercultural Press, 1998. 179 p.

${ }^{24}$ Сазоненко Г.С. Педагогіка успіху (досвід становлення акмеологічної системи ліцею). Київ, 2004. 684 с. 
- and their relatives, help each doctor to develop;

- combination of spontaneity with the possibility of critical situation regulation, ability to work in team;

- focusing on achieving success in treatment, avoiding medical failure, confronting challenges.

The benefits of assertive doctors are less stressed and self-assured as they keep the situation under control as planned and expected; they find the best solutions in urgent situations; patients are treated with dignity, confidence and respect; medical stuff and colleagues feel comfortable and maintain stronger relationships.

Dealing with students' feelings is reflected as an objective characteristic in the nature of interaction between students and teachers explaining why empathy, self-awareness, and self-discipline are essential to success and positive humane interaction in medical profession. The main reason why assertive doctors think differently is that they have higher levels of selfawareness. It is significant to note that openness and receptiveness are manifestations of deeper personality characteristics hidden from the untrained eye. For assertion, or confidence, to be accompanied by a high level of receptiveness some other personality characteristics like selfmonitoring and an internal control are required. They take responsibility for their failures and critically evaluate their own performance, since they do not ascribe the outcomes of their actions to external factors. Thus, assertive personality should have the following characteristics:

1) express freely own thoughts, feelings, and communicate with patients at all levels: this communication is always open, honest, direct and adequate;

2) active attitude to life: to achieve the desired, to try to influence events;

3) self-respect activities;

4) responsibility for every patient and treatment case.

Therefore, determination of educational environment leading to the realization of individual's capacity is considered to be a significant aspect in the problem of medical education. As Goleman ${ }^{25}$ claims, students should be "more academically competent: better able to put their ideas into words, to use and respond to reason, to concentrate, to make plans and follow them, and be more eager to learn". The development of talented medical specialists requires the creation of self-governing system that would provide identification and support of students, the development and implementation of their personal abilities, stimulation of creative work of students and teachers; revitalization of teaching and learning students' activities due to

${ }^{25}$ Goleman D.P. Why It Can Matter More Than IQ. Emotional Intelligence. $10^{\text {th }}$ ed. Random House Publishing Group. 2006. 384 p. 
the creation of appropriate educational environment at educational institutions.

Motivation as a key factor among features of teaching and learning medical students significantly increases social skills and cultural awareness, otherwise it may impede assertiveness. For opportunities to allow assertiveness and to teach skilled assertiveness successfully, educators must know much about their students' temperament, sensitivities, values, preferences, and curiosity. In addition to the positive assessment of their skills and abilities to self-confidence formation, behavioral and environmental components with the belief in its efficacy are also significant.

Thus, an important step in teaching assertiveness is to take a genuine interest in their students and gather useful information for knowing them. Useful information can be obtained by observing behavior, finding out what is being communicated and determining the level of communication the student is capable of. The role of the native language also plays a very essential role in the formation of language culture in medical students, leading to creation of assertiveness. A certain foreign language level means a certain skill level in assertiveness. Efficiency of formation assertiveness in students is based on different types of creative activity (problematical principles and creative tasks).

Nevertheless, teaching students the art of being assertive, confidently asserting their desire and needs without imposing those desire and needs on others, is one of the most common concerns at higher medical educational institutions. Teacher's goal in teaching process and formation of students' assertiveness is to appreciate others, to speak their minds respectfully and to respect their opinions. Successful medical students can expect valuable practical resources, professional guidance and friendly correspondence throughout the entire duration of the studying process.

\section{CONCLUSIONS}

The necessity of humanitarian culture and education of medical students in Ukraine is determined by current educational situation. The importance of demonstrating professional values, principles, and ethics in doctors' daily practice should not be underestimated. Humanitarization of modern education is regarded as a significant factor in teaching medical students and formation of traits of character at all levels of their future career. Interdisciplinary integration can enhance the use of knowledge, personal traits, qualities and practical experience acquired in the study of humanities at medical universities.

It is possible to assert with certain degree of likelihood that the concept of pedagogical incentive is based on deep humanistic sense. Personality formation of a future physician within the culture-formation aspect, is 
carried out in such a way - to direct, instruct and encourage his/her inner spiritual and moral strength, but at the same time - considering the student's age and mental characteristics, to consistently reduce the influence of medical and educational factors which cannot be classified as incentives (punishment, threats, administrative pressure).

Significant steps toward cultural competence requires the establishment of national standards for electronic health care transactions and national identifiers for providers, health insurance plans, and employers. To become assertive and cultural competent means to discuss health issues and health care problems honorably and clearly, to promote prevention, to ensure equity and cultural competence to each patient, and to deliver high-quality care to residents. The majority of professionals have to value the significance of cultural competence education and training relevant to their future practice. Cultural competence training is possibly viewed as an immediately applied phenomenon rather than a holistic, structural approach "defining physician training outcomes in multicultural education". ${ }^{26}$

According to conducted study, one can conclude that second year medical students are acquainted with cultural competence and they are aware of doctors' traits as a person of culture. Morality including bioethics and deontology, good manners, patriotism, honesty, sense of duty, justice and communication with tolerance, sociability, listening skills, veracity, modesty, empathy, thoughtfulness are the most significant for doctors. Unfortunately, independence is regarded as the least significant trait for doctors due to students' survey.

All the functions of human communication, namely: information and communication, organization of interpersonal relationships, cognition of another person, interference, and aesthetics are performed in unity. And if any components are excluded in the process of communication with other individuals, at the same time "failures" will occur in the whole communication mechanism. Special attention should also be paid to cognitive interest, since its influence on the student's personality, and his/her cognitive activity is very essential and one of the leading motives for students' education and self-improvement. An efficient stimulus of the development of cognitive interest is mutual support in the process of communication between a teacher and a student, the emotional tonus of coactivity that stimulates medical student's cognitive capabilities.

The skill of assertiveness is also important for future doctors as it improves doctors' personal, cultural and professional efficacy. Optimizing learning

${ }^{26}$ Tervalon M., Murray-Garcia J. Cultural humility versus cultural competence: a critical distinction in defining physician training outcomes in multicultural education. $J$ Health Care Poor Underserved. 1998. № 9. P. 117-125. 
experience, students should distinguish between assertiveness and reflection. Being assertive means to understand others, to express correctly and speak softly. Senior medical students have more confidence in their abilities and become assertive. They take on greater responsibility for patient care and think, behave and react correctly to patients' and respect their rights.

We should continually aim to improve the quality of education at all levels as to help the citizens adapt to changing needs and circumstances, and achieve the higher educational standards that will be needed to take advantage of the possibilities, and cope with the challenges of the $21^{\text {st }}$ century. Criteria for effective continuing education: convenience, relevance, individualization, self-assessment, independent learning, and systematic approach are the main standards for future health caregivers.

\section{SUMMARY}

The article highlights a new approach to teaching humanities to medical students as a reasonable impact on personality formation. Only with the help of a teacher future caregivers can achieve assertive results in communication with patients and medical staff hiding their feelings or in practical defense of their position and confident attitude to work in a team properly, to defend their point of view, to offer new solutions, to find compromises. Assertiveness as a quality of future caregivers is very important in their career and daily life. The aim of this investigation is to develop practical recommendations for successful integration of cultural competence teaching medical students at Danylo Halytsky Lviv national medical university. The background of cultural competence at higher medical universities can be understood as those acquired skills which help medical students recognize cultural differences and facilitate communication between patients, their relatives and colleagues. Culture competence includes cultural knowledge, sensitivity, awareness, clinical skills and abilities which constitute rules, norms and strategies. The investigation involved 232 second-year students studying General Medicine at Danylo Halytsky Lviv national medical university (2017-2018 academic year). Based on our research, second-year students determined the content of traits of a doctor as "a person of culture" and their significance for future career: spirituality, communication, morality, creativity and independence.

\section{REFERENCES}

1. Бордовская Н.В., Титова Е.В. Качество деятельности преподавателя вуза (подходы к пониманию и оценке). Вестник СЗО РАО «Образование и культура Северо-Запада России». СанктПетербург, 2002. Вып. 7. С. 192-206. 
2. Сазоненко Г.С. Педагогіка успіху (досвід становлення акмеологічної системи ліцею). Київ, 2004. 684 с.

3. Скотникова И.Г. Проблема уверенности: история и современное состояние. Психологический журнал. Москва, 2002. Т. 23. № 1. С. 52-60.

4. Теличко Н.В. Організація навчання обдарованих молодших школярів у США : автореф. дис. ... канд. пед. наук. Івано-Франківськ, 2005. $21 \mathrm{c}$.

5. Фокин Ю.Г. Преподавание и воспитание в высшей школе: Методология, цели и содержание, творчество : учебное пособие для студ. высш. учеб. заведений. Москва, 2002. 224 с.

6. Banaji S., Cranmer S. \& Perrotta C. Expert Perspectives on Creativity and Innovation in European Schools and Teacher Training. Luxembourg: European Commission Joint Research Centre Institute for Prospective Technological Studies. 2010. URL: http://ftp.jrc.es/EURdoc/ JRC59833_TN.pdf.

7. Balzora S., Abiri B., Wang X.J., McKeever J., Poles M., Zabar S., ... Weinshel E. Assessing cultural competency skills in gastroenterology fellowship training. World Journal of Gastroenterology. 2015. № 21 (6). P. 1887-1892. DOI: 10.3748/wjg.v21.i6.1887.

8. Beach M.C., Price E.G., Gary T.L., Robinson K., Gozu A., Palacio A., Smarth C., Jenckes M., Feuerstein C., Bass E.B., Powe N.R. \& Cooper L.A. Cultural competence: A systematic review of health care provider educational interventions. Medical Care. 2005. № 43. P. 356-373. DOI 10.1097/01.mlr.0000156861.58905.96.

9. Betancourt J.R. Cross-cultural medical education: conceptual approaches and frameworks for evaluation. Acad Med. 2003. № 78 (6). P. 560-569. DOI: 10.1097/00001888-200306000-00004.

10. Bittersweet K. Preparing 21st Century Students for a Global Society An Educator's Guide to the "Four Cs" Great Public Schools for Every Student. 38 p. URL: www.nea.org > assets > docs >.

11. Brady R. \& Edelman L.A. State of Create Global Benchmark Study: Global Benchmark Study on Attitudes and Beliefs about Creativity at Work, School and Home. 2012. URL: https://www.adobe.com/aboutadobe/ pressroom/pd fs/.

12. Dobbie A.E., Medrano M., Tysinger J., Olney C. The BELIEF instrument: a preclinical teaching tool to elicit patients' health beliefs. Family Medicine. 2003. № 35. P. 316-319.

13. Goleman D.P. Why It Can Matter More Than IQ. Emotional Intelligence. $10^{\text {th }}$ ed. Random House Publishing Group. 2006. 384 p.

14. Hall E.T., Hall M.R. Hidden Differences: Doing Business with the Japanese. Anchor Press. Doubleday. Garden City : NY, 1987. P. 16-18. 
15. Isayeva O. Modeling Cultural Competence in Teaching Humanities to Medical Students. American Journal of Educational Research (Education). 2014. Vol. 2 (12B). P. 51-55. URL: http://www.sciepub.com/education/content/2/12B.

16. King M.A., Sims A. \& Osher D. How is cultural competence integrated into education? Washington. D.C. : Center or Effective Collaboration and Practice. American Institutes for Research, 2007. URL: http://cecp.air.org/cultural/Q_integrated.htm.

17. Makoul G. Essential elements of communication in medical encounters: The Kalamazoo Consensus Statement. Acad. Med. 2001. № 76 (4). P. 390-393.

18. Moule J. Cultural Competence: A primer for educators. Belmont, CA : Wadsworth, 2011. 384 p. ISBN-10: 0495915297.

19. Mukan N., Yaremko H., Kozlovskiy Yu., Ortynskiy V., Isayeva O. Teachers' continuous professional development: Australian experience. Advanced Education. 2019. № 12. P. 105-113. DOI: 10.20535/24108286.166606.

20. Robbins S.P. Understanding cultural differences. Organizational Behavior. Yarmouth. ME : Intercultural Press, 1998. 179 p.

21. Seeleman C., Hermans J., Lamkaddem M., Suurmond J., Stronks K., Essink-Bot M.L. A students' survey of cultural competence as a basis for identifying gaps in the medical curriculum. BMC Med Educ. 2014. URL: https://doi.org/10.1186/1472-6920-14-216.

22. Stein S.J., Book H.E. The EQ Edge: Emotional Intelligence and Your Success Jossey-Bass; 3 edition. 2011. 368 p. ISBN-13: 978-0470681619.

23. Tervalon M., Murray-Garcia J. Cultural humility versus cultural competence: a critical distinction in defining physician training outcomes in multicultural education. J Health Care Poor Underserved. 1998. № 9. P. 117-125.

24. Correlation between creativity and independence 20 Position $\% 2$. URL: https://www.oecd.org/education/.../E2030\%.

Information about the author: Isayeva O. S.,

Full Professor, ScD (Education), Department of Foreign Languages Lviv Polytechnic National University, 12, Stepan Bandera str., Lviv, 79000, Ukraine ORCID ID: orcid.org/0000-0002-1832-739X 